\title{
East European crayfish stocks at risk: arrival of non-indigenous crayfish species
}

\author{
Ganna Kotovska $^{1}$, Dmytro Khrystenko ${ }^{1,2, *}$, Jiří Patoka ${ }^{3, a}$ and Antonín Kouba ${ }^{4, a}$ \\ ${ }^{1}$ Institute of Fisheries of the National Academy of Agrarian Sciences of Ukraine, Obuhivska 135, Kyiv 03164, Ukraine \\ ${ }^{2}$ Cornell University, College of Agriculture and Life Sciences, International Programs, B75 Mann Library, Ithaca, NY 14853, USA \\ ${ }^{3}$ Czech University of Life Sciences Prague, Faculty of Agrobiology, Food and Natural Resources, Department of Zoology and Fisheries, \\ Kamýcká 129, Prague 6-Suchdol 165 21, Czech Republic \\ ${ }^{4}$ University of South Bohemia in České Budějovice, Faculty of Fisheries and Protection of Waters, South Bohemian Research Center of \\ Aquaculture and Biodiversity of Hydrocenoses, Zátisí 728/II, Vodňany 389 25, Czech Republic
}

\begin{abstract}
An increasing number of non-indigenous crayfish species (NICS) of apparently pet trade origin have become established particularly in Europe. Especially alarming are recent confirmation of two distantly separated marbled crayfish Procambarus fallax f. virginalis populations in Ukraine and indications of more North American cambarids present in the local pet market. The present study aimed to investigate crayfish species availability within the Ukrainian pet trade together with the climate match and risk they represent to the freshwater ecosystems generally and indigenous crayfish species in particular. Altogether, 15 NICS belonging to all three crayfish families were detected. Considering their origin, availability, probability of establishment, invasiveness and further aspects, marbled crayfish and red swamp crayfish Procambarus clarkii appear to be potentially the most troubling. Available information obtained from the pet trade in ornamental crayfish as a whole demonstrates that the broad availability of NICS most probably overlaps the vast majority of European indigenous crayfish species distribution, including the endemic thick-clawed crayfish Astacus pachypus, which occupies only a limited area that is situated critically close to established marbled crayfish populations. Negative effects of NICS on freshwater ecosystems as a whole can be also expected.
\end{abstract}

Keywords: Ukraine / pet trade / ornamental animal / invasiveness / aquarium

Résumé - Les stocks d'écrevisses d'Europe orientale en danger : l'arrivée d'espèces d'écrevisses non indigènes. Un nombre croissant d'espèces d'écrevisses non indigènes (NICS) apparemment d'origine liée à l'aquariophilie se sont établies en particulier en Europe. La confirmation récente de deux populations très éloignées d'écrevisses marbrées Procambarus fallax $\mathrm{f}$. virginalis en Ukraine et des indications d'autres cambaridés nord-américains présentes sur le marché local d'aquariophilie sont les plus alarmantes. La présente étude a pour but d'étudier la disponibilité des espèces d'écrevisses dans le commerce ukrainien des animaux, ainsi que les contraintes climatiques et les risques qu'ils représentent pour les écosystèmes d'eau douce en général et les espèces d'écrevisses autochtones en particulier. Au total, 15 NICS appartenant à trois familles d'écrevisses ont été détectées. Compte tenu de leur origine, leur disponibilité, leur probabilité d'établissement, leur invasivité et d'autres aspects, l'écrevisse marbrée et l'écrevisse de Louisiane Procambarus clarkii semblent être potentiellement les plus inquiétantes. Les informations disponibles provenant du commerce des écrevisses d'ornement dans son ensemble démontrent que la grande disponibilité des NICS chevauche très probablement la grande majorité des distributions des espèces d'écrevisses indigènes européennes, y compris l'endémique écrevisse à grosses pattes Astacus pachypus, qui occupe seulement une zone limitée située très près de populations d'écrevisses marbrées établies. Des effets négatifs des NICS sur les écosystèmes d'eau douce dans son ensemble peuvent également être attendus.

Mots-clés : Ukraine / animaux de compagnie / animaux d'ornement / invasivité / aquarium

\footnotetext{
* Corresponding author: dskhrist@gmail.com

${ }^{a}$ These authors contributed equally to this work.
} 


\section{Introduction}

Species introductions have been recognized as constituting an important driver behind biodiversity loss worldwide (Strayer, 2010; Catford et al., 2012), while it is evident that organisms inhabiting freshwater ecosystems are particularly vulnerable (Moorhouse and Macdonald, 2015). This is true also for freshwater crayfish (Decapoda: Astacida) in Europe, inasmuch as the number of indigenous crayfish species (ICS) have been outnumbered by at least twice by non-indigenous crayfish species (NICS) (Holdich et al., 2009; Kouba et al., 2014).

Due to the obvious ecological importance of crayfish, they are considered keystone and flagship species as well as ecosystem engineers in freshwater ecosystems (Souty-Grosset et al., 2006; Twardochleb et al., 2013). Moreover, crayfish have been eaten by humans for millennia (Patoka et al., 2014a) and even today are fished or cultured (Ackefors, 2000; Wang et al., 2015). Particularly thanks to their large body size, mainly noble crayfish Astacus astacus (Linnaeus, 1758) and narrow-clawed crayfish $A$. leptodactylus sensu lato have been used for human consumption in Europe (Swahn, 2004; Harlioglu, 2011). Unfortunately, their stocks started to diminish in the second half of the 19th century due to a number of reasons. Particularly the introduction of crayfish plague was a key factor in the decline of crayfish stocks (Bohman et al., 2006; Koutrakis et al., 2007; Kozubíková et al., 2008). The crayfish plague pathogen is probably one of the best-known oomycete diseases, and Aphanomyces astaci Schikora, 1906 is one of the best-studied invertebrate pathogens (Rezinciuc et al., 2016). It is considered to be the most devastating disease to all crayfish not originating from North America (Lodge et al., 2000; Svoboda et al., 2016). Unsurprisingly, it is also listed among the worst invasive species in Europe (Vilà et al., 2010) as well as worldwide (Lowe et al., 2000).

Resultant extinctions of European indigenous crayfish populations led to a search for species comparable in ecological and gastronomical characteristics (Svärdson, 1995), and these characteristics were recognized in three North American representatives. These were the spiny-cheek crayfish Orconectes limosus (Rafinesque, 1817) introduced for the first time in the territory of present-day Western Poland in 1890, followed by the signal crayfish Pacifastacus leniusculus (Dana, 1852) introduced to Sweden in 1959, and the red swamp crayfish Procambarus clarkii (Girard, 1852) introduced to Spain in 1973. These are often referred to in the literature as "Old" NICS (Holdich, 2002; Holdich et al., 2009). All these crayfish are particularly widespread across the continent today (Kouba et al., 2014). Sadly, it became apparent in the course of time that North American crayfish species are chronic carriers of the mentioned disease and serve as its vectors (Unestam, 1972).

The main reason for Old NICS introductions in Europe was originally their expected commercial use in fisheries and aquaculture. Up to the present day, however, introductions are ongoing of additional NICS (often termed "New" NICS) that are usually kept as ornamental animals in aquaria (Holdich et al., 2009; Kouba et al., 2014). The species most available on the market originate from North America and may either accidentally escape or, more likely, are intentionally released into the wild by their keepers, thereby endangering their indigenous counterparts (Chucholl, 2013; Papavlasopoulou et al., 2013; Patoka et al., 2014b, c).

The pet trade in aquatic animals is a dynamically growing sector of aquaculture. The international trade has been increasing by an average 14\% per year since 1985 and now can be measured in billions of US dollars (Padilla and Williams, 2004; Rani et al., 2014). The bulk of the traded animals is imported to the USA, EU, and Japan (Padilla and Williams, 2004; Ploeg, 2013). Although freshwater fishes comprise the core of this sector (Silas et al., 2011; Magalhães and Jacobi, 2013), freshwater crayfish have been recognized as constituting a significant part and their popularity has been increasing in recent decades (Chucholl, 2013). Unfortunately, negative consequences resulting from the release of New NICS into natural habitats are particularly apparent in Europe (Chucholl, 2013; Faulkes, 2015a; Patoka et al., 2015). These New NICS usually belong to the North American taxa, and individuals of pet trade origin also have been confirmed as infected by the crayfish plague pathogen (Kouba et al., 2014; Mrugała et al., 2015).

Risk of crayfish pet trade have been already studied in several European countries, including the Czech Republic (Patoka et al., 2014b), Germany (Chucholl, 2013), Greece (Papavlasopoulou et al., 2013), Italy (Tricarico et al., 2010), Slovakia (Lipták and Vitázková, 2015), Turkey (Turkmen and Karadal, 2012), Canada (Faulkes, 2013) and USA (Faulkes, 2015b). Marbled crayfish Procambarus fallax f. virginalis Martin et al., 2010 was always determined to be the first or second most available species and with the highest estimations of invasiveness. Its origin has been exclusively from aquariumbred individuals inasmuch as native populations of this species are not yet known (Martin et al., 2016). Marbled crayfish has become established particularly in Germany (Chucholl et al., 2012), but the species also is reported from Croatia (Samardžić et al., 2014), Italy (Nonnis Marzano et al., 2009; Vojkovská et al., 2014), Hungary (Weiperth et al., 2015; Lőkkös et al., 2016), the Netherlands (Koese, 2008), Slovakia (Janský and Mutkovič, 2010; Lipták et al., 2016), and Sweden (Bohman et al., 2013). Species availability in the pet market, environmental requirements, and socio-economic predictors such as gross domestic product and human population density have been recognized as key drivers behind the occurrence of marbled crayfish (Perdikaris et al., 2012; Chucholl, 2014, 2015). Inasmuch as fewer NICS have become established in Eastern Europe and problems with NICS in this region (and with New NICS in particular) have generally been fewer, these have been much less investigated in this region (Feria and Faulkes, 2011; Perdikaris et al., 2012; Kouba et al., 2014; Faulkes, 2015c). Nevertheless, recent confirmation of two distant marbled crayfish populations in Ukraine and indications of more North American cambarids occurring in the local pet market are particularly alarming (Novitsky and Son, 2016), because hitherto East European crayfish stocks have been considered relatively safe from adverse impacts of NICS and the closely related crayfish plague.

The present study aimed to investigate the availability of crayfish species in the Ukrainian pet trade while examining their climate match and assessing the risk they pose to the freshwater ecosystems generally and to native astacofauna in particular. 


\section{Material and methods}

\subsection{Data collection}

Information about crayfish species within the pet trade and their availability in the market of Ukraine were obtained during February and March 2016 Interviews were conducted with one wholesaler in Kiev and four pet shop owners in Kiev, Dnepropetrovsk, Odessa, and Kharkiv. Four pet bazaars were also visited in Kiev, Dnepropetrovsk, Odessa, and Kharkiv. These regional centres have one big specialised place where people without any permit can sell, exchange, and buy pets, although they officially are required only to have veterinary documents on the health status of the animals and to pay a tax at the end of the year. Advertised species were recorded and photographed for later identification. Also offer lists and catalogues of two national on-line shops had been monitored over the collection period: OLX (http://olx.ua/zhivotnye/ akvariumnye-rybki/q- $\%$ D $1 \% 80 \%$ D0 $\%$ B0 $\%$ D0 $\%$ BA $\%$ D $0 \%$ B8/) and Nanofish (http://www.nanofish.com.ua/raki-i-kraby. html). Collected records were subsequently clarified during personal visits, and misnomers and alternative trade names were eliminated with the aid of various related scientific publications (e.g. Albaugh and Black, 1973; Lukhaup and Pekny, 2006; Souty-Grosset et al., 2006; Martin et al., 2010). Our survey was not focused on human subjects themselves. We only present data about legally traded animals offered at the public market. According to Ukrainian laws, this information must be provided to potential customers, it is open to public and anybody have rights to collect it. We did not obtain, collect and present any private information about traders.

Furthermore, a general survey among the leading Czech wholesalers to verify export to Ukraine from the Czech Republic, which is one of the leading European markets with aquarium species was processed.

\subsection{Market availability}

Market availability was evaluated for each species according to Chucholl (2013) using the following criteria: (i) "very rare" species available only for a short period and in small quantities, (ii) "rare" species available occasionally in small quantities, (iii) "common" species available frequently in small quantities, and (iv) "very common" species always available in large quantities.

\subsection{Climate match}

Climatic conditions were represented in our analysis by the variable temperature during the coldest quarter of the year. The climate match between source and target area was compared using the Climatch tool (v.1.0; Invasive Animals Cooperative Research Centre, Bureau of Rural Sciences, Australia). As the source area, we used the region which is the native geographic range of a given evaluated species. In the case of Procambarus fallax f. virginalis, the native region of which is not yet known, the source region was taken, in accordance with Chucholl (2014), as the verified European localities where it has established populations. The target area was defined as the territory of Ukraine containing
93 climatic stations from the database of the WordClim project (Hijmans et al., 2005). Where the climate match between the source area and the climatic station in the target area reached a score of $\geq 7.0$, this was interpreted as there is no environmental barrier to survival.

\subsection{Risk assessment}

To evaluate the potential invasiveness of crayfish traded in Ukraine, we used the Freshwater Invertebrate Invasiveness Scoring Kit produced by the UK Centre for Environment, Fisheries \& Aquaculture Science (FI-ISK, v.1.19; Tricarico et al., 2010). Based on the FI-ISK score, each evaluated species was subsequently classified as (i) low-risk (score $<1$ ), (ii) medium-risk (score $\geq 1$ but $<16$ ), or (iii) high-risk (score $\geq 16$ ) from a Ukrainian perspective.

\section{Results}

A total of 15 species belonging to all three crayfish families (Astacidae, Cambaridae, and Parastacidae) were found to be marketed in Ukraine (Tab. 1). They are considered as NICS throughout Europe. All the ten market-traded species are indigenous to North America. All market-traded species are from the family Cambaridae except for the signal crayfish, which belongs to the Astacidae. The remaining five species are parastacids indigenous to Australia and/or New Guinea. Two species (signal crayfish and red swamp crayfish) are classified as Old and 13 species as New NICS (cf. after Holdich et al., 2009). Marbled crayfish, red swamp crayfish, orange morph of Mexican dwarf Cambarellus patzcuarensis Villalobos (1943), and redclaw Cherax quadricarinatus (Von Martens, 1868) are the species very common on the market.

Based upon climate match, four marketed NICS (signal crayfish, red swamp crayfish, marbled crayfish, and common yabby $C$. destructor Clark, 1936) were classified as being able to survive under the Ukrainian climatic conditions at least within parts of the country (Fig. 1). The greatest climatic compatibility and similarity among all the evaluated species was found in signal crayfish and marbled crayfish.

FI-ISK scores ranged between 3 and 32. No species was classified as low-risk, 11 species were classified as mediumrisk and four species were classified in the high-risk category (Tab. 1). All high-risk species have also the highest climate match. The highest FI-ISK score among the evaluated species was that of marbled crayfish, followed by red swamp crayfish.

\section{Discussion}

The introduction, establishment, and subsequent spread of NICS is known to be one of the main factors seriously affecting European ICS (Peay, 2009; Gherardi et al., 2011; Chucholl, 2014) and the pet trade has been recognized as an important source of freshwater species introductions worldwide (Padilla and Williams, 2004; Duggan, 2010; Chucholl, 2013). The pet trade began importing crayfish and then also domestically producing them for ornamental purposes around the mid-1990s (Faulkes, 2010; Patoka et al., 2015), and already today several such species can be found in European freshwaters (Chucholl, 2013; Kouba et al., 2014). 
Table 1. List of non-indigenous crayfish species within the pet trade in Ukraine $\mathrm{VC}=$ very common, $\mathrm{C}=$ common, $\mathrm{R}=$ rare, $\mathrm{VR}=\mathrm{very}$ rare.

\begin{tabular}{|c|c|c|c|c|c|c|}
\hline Species name & Family & Domestic trade name & $\begin{array}{l}\text { Market } \\
\text { availability }\end{array}$ & $\begin{array}{l}\text { NICS } \\
\text { status }\end{array}$ & $\begin{array}{l}\text { FI-ISK } \\
\text { score }\end{array}$ & $\begin{array}{l}\text { FI-ISK } \\
\text { category }\end{array}$ \\
\hline Pacifastacus leniusculus & Astacidae & Американский сигнальный рак & VR & Old & 23 & High \\
\hline Cambarellus diminutus & Cambaridae & Карликовый синий рак & VR & New & 3 & Medium \\
\hline Cambarellus patzcuarensis (orange morph) & Cambaridae & Карликовый оранжевый рак & $\mathrm{VC}$ & New & 4 & Medium \\
\hline Cambarellus puer & Cambaridae & Карликовый болотный рак & VR & New & 3 & Medium \\
\hline Cambarellus texanus & Cambaridae & Карликовый разукрашенный рак & VR & New & 3 & Medium \\
\hline Procambarus alleni (blue morph) & Cambaridae & Флоридский синий рак & $\mathrm{C}$ & New & 11 & Medium \\
\hline $\begin{array}{l}\text { Procambarus clarkii (full red, orange, white, } \\
\text { and blue morphs) }\end{array}$ & Cambaridae & Красный флоридский рак & $\mathrm{VC}$ & Old & 30 & High \\
\hline Procambarus cubensis & Cambaridae & Голубой кубинский рак & VR & New & 7 & Medium \\
\hline Procambarus fallax f. virginalis & Cambaridae & Мраморный рак & $\mathrm{VC}$ & New & 32 & High \\
\hline Procambarus milleri & Cambaridae & Мандариновый рак & VR & New & 3 & Medium \\
\hline Cherax quadricarinatus & Parastacidae & $\begin{array}{l}\text { Австралийский } \\
\text { красноклешнёвый рак }\end{array}$ & $\mathrm{VC}$ & New & 13 & Medium \\
\hline Cherax destructor & Parastacidae & Ябби разрушитель & $\mathrm{C}$ & New & 20 & High \\
\hline Cherax holthuisi & Parastacidae & Абрикосовый рак & $\mathrm{R}$ & New & 3 & Medium \\
\hline Cherax peknyi & Parastacidae & Полосатый рак & VR & New & 4 & Medium \\
\hline Cherax pulcher & Parastacidae & Голубая луна & $\mathrm{R}$ & New & 4 & Medium \\
\hline
\end{tabular}
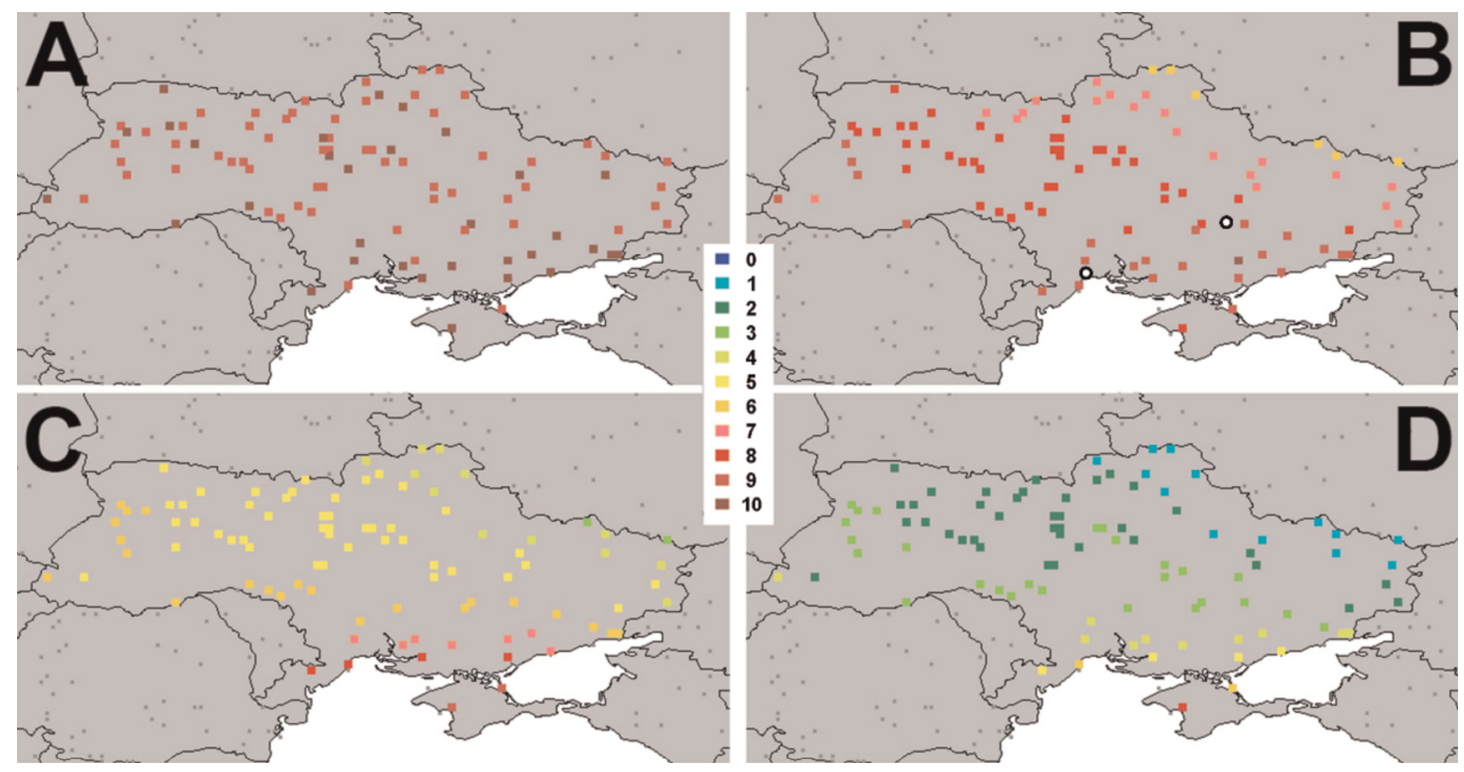

Fig. 1. Climate match maps of Ukraine showing areas with highest probability of establishment for the NICS evaluated as high-risk species (evaluated by model as high-risk); scores of $\geq 7.0$ are interpreted as there is no environmental barrier to survival; A = Pacifastacus leniusculus, $\mathrm{B}=$ Procambarus fallax $\mathrm{f}$. virginalis (note that the species is already established in the country - indicated by black circles), $\mathrm{C}=$ Procambarus clarkii; $\mathrm{D}=$ Cherax destructor.

Keeping NICS is not prohibited in Ukraine, and no permit is needed for home rearing. The relevant national law, "On protection of animals against cruelty" N 3447-IV, dated 21 December 2006, states in its Clause 1 that pets are dogs, cats and other living organisms (without closer specification) kept and bred by man. Clause 2 specifies that this law covers breeding, hunting, fishing, keeping at home and zoos, and so forth. Cruel treatment of any living organism that is kept at home - and thus even of crayfish - might (at least in theory) lead to expropriation of the animal(s) and a penalty equivalent to ca EUR 2.00-6.00, depending on a court's decision. Commercial producers must have only veterinary documents as to the health status of animals. These documents are relatively easy to obtain, however, as overall health appearance and absence of external parasites is evaluated and no examination is made for any specific crayfish-related disease. Prior to August 2015, a special licence was required under Clause 14 of the law mentioned above to undertake this kind of business. This obligation was recently repealed by the law "On amendments to some laws of Ukraine on 
simplification of business conditions in Ukraine" N 1759-17, dated 28 June 2015.

Pet shop owners must have a permit for this type of business activity, veterinary documents on crayfish health status, and full information about species and the peculiarities of their keeping. In addition to paying taxes, any person (a hobby grower) selling pets officially needs to have veterinary documents regarding the health status of animals. The enforceability of these formal requirements is nevertheless very limited, and particularly so if transactions are conducted via internet. Moreover, any possible penalty is only very modest. Releasing alien species into the wild is banned by the law "On Wildlife" N 2894-III, dated 13 December 2001. Penalties under that law are in the range of ca EUR 6.00-12.00.

Knowing that Czech Republic is an export hub for ornamental aquatic animals into the European Union (EU) and the adjacent region (Kalous et al., 2015; Patoka et al., 2015; Kopecký et al., 2016), a general survey was made among the leading Czech wholesalers. This survey provided no evidence of direct ornamental crayfish export to Ukraine. This nevertheless does not exclude the possibility that they might be re-exported via third countries (in particular via Russian Federation, which itself has a sizeable domestic production of aquarium organisms). Indeed, the information obtained indicates that at least a part of the ornamental crayfish were imported from Russian Federation, particularly prior to 2014. Inasmuch as the political situation remains complicated in Ukraine's region due to Russia-Ukraine conflict, decline of imports from Russian Federation and direct importing from Southeast Asia also has been established while its exact magnitude is unknown (Anonymous, pers. comm., 2016). In 2015 majority of red swamp crayfish and redclaw had Southeast Asian origin.

Germany and the Czech Republic, with 120 and 27 NICS, respectively, have been identified as leading European countries in terms of the availability within their borders of ornamental crayfish species (Chucholl, 2013; Patoka et al., 2014b). Several socio economic and demographic factors (e.g. human population density and gross domestic product) have been found to be drivers of NICS spread among European territories (Chucholl et al., 2012; Perdikaris et al., 2012; Chucholl, 2015). General patterns of pet market-traded crayfish species suggest that more species are available in industrialized Western European countries (particularly if their trading is not banned). Generally lower economic spending power and to some degree a related delay in the development of internet-based commerce have in the past helped at least in part to save Eastern Europe from NICS establishment (Perdikaris et al., 2012). Nevertheless, that situation is apparently changing very quickly in the case of the crayfish pet trade. In this context, the detection of 15 NICS in this study (Tab. 1) is truly alarming. Based upon various surveys conducted of the pet trade in crayfish, the range of NICS offered for sale in Ukraine is the highest after those of Germany (Chucholl, 2013), the Czech Republic (Patoka et al., 2014b), and the United States (Faulkes, 2015b). Two-thirds of these species are native to North American and thus are potential carriers of crayfish plague. Furthermore, at least four species are very common and/or show high degrees of invasiveness risk (Tab. 1).
The best climate match (Fig. 1) is that of signal crayfish, a species that is the most widespread NICS on the European continent (Kouba et al., 2014). Although its potential invasiveness is considered high, its overall importance is at least partly limited due to its scarcity in the market (Tab. 1). Another potentially highly invasive species that finds suitable climate in Ukraine and which is common in the market is common yabby (Tab. 1, Fig. 1). Despite its rapid growth rates and large body length, it is unlikely that such an expensive species (Chucholl, 2013; Patoka et al., 2014b) would be released into the wild in large quantities ( $c f$. Van Wilgen et al., 2010).

Considering its availability in the market, potential invasiveness with a good climate match, and North American origin, red swamp crayfish and the already established marbled crayfish (Novitsky and Son, 2016) are the most dangerous. These species had been identified as the most common also in other European countries where the pet trade in crayfish was analysed, such as in Germany (Chucholl, 2013) and in the Czech Republic (Patoka et al., 2014b, 2014c). Concerns as to their further spread are fully justified inasmuch as their occurrence is powerfully driven by propagule pressure relating to the pet trade (Chucholl, 2014, Faulkes, 2015a).

There is an extensive literature on negative effects of red swamp crayfish on ICS stocks as well as other taxonomic groups within invaded ecosystems (Souty-Grosset et al., 2016). These include changes in species composition and abundance of aquatic plants (Gherardi and Lazzara, 2006; Gherardi and Acquistapace, 2007), insects, molluscs, as well as eggs and developmental stages of amphibians and fish (Cruz et al., 2008; Reynolds, 2011). Its burrowing activity damages embankments and dams and can result in water leakage (Souty-Grosset et al., 2016). Red swamp crayfish can also cause damage in agriculture, and a combination of burrowing and consumption of aquatic plants leads to an undesirable increase in water turbidity that can alter an entire ecosystem and its food webs (Anastacio et al., 2005; Rodriguez et al., 2005).

Less information on negative effects is known from European localities inhabited by the marbled crayfish (Lipták et al., 2016) because its viable populations were found only recently. For example, populations in Germany and Slovakia were found in 2010 (Janský and Mutkovič, 2010; Chucholl et al., 2012). Nevertheless, its attributes are largely similar to the aforementioned species: easy culture, rapid growth, early maturation, high fecundity, short embryogenesis, and multiple annual reproduction cycles (Vogt and Tolley, 2004; Seitz et al., 2005; Vogt, 2008; Vogt, 2015). Furthermore, marbled crayfish reproduce through obligate parthenogenesis. Offspring of individual females are genetically identical triploids (Seitz et al., 2005; Martin et al., 2007; Martin et al., 2016).

Both mentioned species tolerate low winter temperatures (Veselý et al., 2015), are capable burrowers (Kouba et al., 2016) and animals both from the pet trade and the wild are confirmed carriers of the crayfish plague pathogen (Keller et al., 2014; Mrugała et al., 2015). Taking this information as a whole, it is not surprising that both species are considered the very dangerous possible invaders (Tricarico et al., 2010; Chucholl, 2013; Patoka et al., 2014b). Unfortunately, hobbyists culturing these crayfish are soon faced with a problem of how to deal with the excess numbers of these 
rapidly reproducing crayfish. For at least some of them, release into the wild apparently seems a more feasible solution than to destroy the unwanted offspring (Patoka et al., 2014c). The consequences of such action could be far-reaching, impacting upon the invaded ecosystems generally and ICS in particular. East European crayfish stocks have been considered relatively safe from the presence of NICS and related crayfish plague (Holdich et al., 2009; Kouba et al., 2014). This region contains core parts of the narrow-clawed crayfish area, and established marbled crayfish populations (Novitsky and Son, 2016) are critically close to locations where the thick-clawed crayfish Astacus pachypus (Rathke, 1837) is endemic. Thick-clawed crayfish is a species with only limited distribution (Kouba et al., 2014). Thus, feasibility of actions eradicating marbled crayfish populations should be considered. Moreover, possible negative effects of additional pet market-traded species cannot by completely ruled out. Target monitoring of the situation is needed, as is education of stakeholders from the aquarium industry (importers, shop owners, breeders, and hobbyists) with a focus on the risks related to discharge of aquarium water with theoretical presence of crayfish plague pathogen and release of ornamental organisms.

Acknowledgements. This study was supported by the Internal Grant Agency of the Czech University of Life Sciences Prague "CIGA" (No. 20152007), and the Ministry of Education, Youth and Sports of the Czech Republic - projects "CENAKVA" (No. CZ.1.05/2.1.00/01.0024) and "CENAKVA II" (No. LO1205 under the NPU I program). We thank English Editorial Services, s.r.o. for language editing. We appreciate constructive criticism of Zen Faulkes and a reviewer that stayed anonymous.

\section{References}

Ackefors HE. 2000. Freshwater crayfish farming technology in the 1990s: a European and global perspective. Fish Fish 1: 337-359.

Albaugh DW, Black JB. 1973. A new crawfish of the genus Cambarellus from Texas, with new Texas distributional records for the genus (Decapoda, Astacidae). Southwest Nat 18: 177-185.

Anastacio PM, Correia AM, Menino JP. 2005. Processes and patterns of plant destruction by crayfish: effects of crayfish size and developmental stages of rice. Arch Hydrobiol 162: 37-51.

Bohman P, Nordwall F, Edsman L. 2006. The effect of the large-scale introduction of signal crayfish on the spread of crayfish plague in Sweden. B Fr Pêche Piscic 380-381: 1291-1302.

Bohman P, Edsman L, Martin P, Scholtz G. 2013. The first Marmorkrebs (Decapoda: Astacida: Cambaridae) in Scandinavia. BioInvasions Rec 2: 227-232.

Catford JA, Vesk PA, Richardson DM, Pysek P. 2012. Quantifying levels of biological invasion: towards the objective classification of invaded and invasible ecosystems. Glob Change Biol 18: 44-62.

Chucholl C. 2013. Invaders for sale: trade and determinants of introduction of ornamental freshwater crayfish. Biol Invas 15: $125-141$.

Chucholl C. 2014. Predicting the risk of introduction and establishment of an exotic aquarium animal in Europe: insights from one decade of Marmorkrebs (Crustacea, Astacida, Cambaridae) releases. Manag Biol Invas 5: 309-318.

Chucholl C. 2015. Marbled crayfish gaining ground in Europe: the role of the pet trade as invasion pathway. In: Kawai T, Faulkes Z,
Scholtz G, eds. Freshwater crayfish: a global overview. CRC Press, pp. 83-114.

Chucholl C, Morawetz K, Gross H. 2012. The clones are coming strong increase in Marmorkrebs Procambarus fallax (Hagen, 1870) f. virginalis records from Europe. Aquat Invas 7: 511-519.

Cruz MJ, Segurado P, Sousa M, Rebelo R. 2008. Collapse of the amphibian community of the Paul do Boquilobo Natural Reserve (central Portugal) after the arrival of the exotic American crayfish Procambarus clarkii. Herpetol J 18: 197-204.

Duggan IC. 2010. The freshwater aquarium trade as a vector for incidental invertebrate fauna. Biol Invas 12: 3757-3770.

Faulkes Z. 2010. The spread of the parthenogenetic marbled crayfish, Marmorkrebs (Procambarus sp.), in the North American pet trade. Aquat Invas 5: 447-450.

Faulkes Z. 2013. How much is that crayfish in the window? Online monitoring of Marmorkrebs, Procambarus fallax f. virginalis (Hagen, 1870) in the North American pet trade. Freshwater Crayfish 19: 39-44.

Faulkes Z. 2015a. The global trade in crayfish as pets. Crustacean Res 44: 75-92.

Faulkes Z. 2015b. Marmorkrebs (Procambarus fallax f. virginalis) are the most popular crayfish in the North American pet trade. Knowl Manag Aquat Ecosyst 416: 20.

Faulkes Z. 2015c. A bomb set to drop: parthenogenetic Marmorkrebs for sale in Ireland, a European location without non-indigenous crayfish. Manag Biol Invas 6: 111-114.

Feria TP, Faulkes Z. 2011. Forecasting the distribution of Marmorkrebs, a parthenogenetic crayfish with high invasive potential, in Madagascar, Europe, and North America. Aquat Invas 6: 55-67.

Gherardi F, Acquistapace P. 2007. Invasive crayfish in Europe: the impact of Procambarus clarkii on the littoral community of a Mediterranean lake. Freshw Biol 52: 1249-1259.

Gherardi F, Lazzara L. 2006. Effects of the density of an invasive crayfish (Procambarus clarkii) on pelagic and surface microalgae in a Mediterranean wetland. Arch Hydrobiol 165: 401-414.

Gherardi F, Aquiloni L, Dieguez-Uribeondo J, Tricarico E. 2011. Managing invasive crayfish: is there a hope? Aquat Sci 73: 185-200.

Harlioglu AG. 2011. Present status of fisheries in Turkey. Rev Fish Biol Fisher 21: 667-680.

Hijmans RJ, Cameron SE, Parra JL, Jones PG, Jarvis A. 2005. Very high resolution interpolated climate surfaces for global land areas. Int J Climatol 25: 1965-1978.

Holdich DM. 2002 Distribution of crayfish in Europe and some adjoining countries. B Fr Pêche Piscic 367: 611-650.

Holdich DM, Reynolds JD, Souty-Grosset C, Sibley PJ. 2009. A review of the ever increasing threat to European crayfish from non-indigenous crayfish species. Knowl Manag Aquat Ecosyst 394-395: 11.

Janský V, Mutkovič A. 2010. Rak Procambarus sp. (Crustacea: Decapoda: Cambaridae) - Prvy Nález na Slovensku [Marbled crayfish - Procambarus sp. (Crustacea: Decapoda: Cambaridae) first find in Slovakia]. Zbornik Slovenského Národneho Múzea (Acta rerum naturalium Musei Nationalis Slovaci Bratislava) 56: 64-67.

Kalous L, Patoka J, Kopecký O. 2015. European hub for invaders: risk assessment of freshwater aquarium fishes exported from the Czech Republic. Acta Ichthyol Piscat 45: 239-245.

Keller N, Pfeiffer M, Roessink I, Schulz R, Schrimpf A. 2014. First evidence of crayfish plaque agent in populations of the marbled caryfish (Procambarus fallax forma virginalis). Knowl Manag Aquat Ecosyst 414: 8. 
Koese B. 2008. Rivierkreeften proeftabel. Naturalis, Leiden, 17 p.

Kopecký O, Patoka J, Kalous L. 2016. Establishment risk and potential invasiveness of the selected exotic amphibians from pet trade in the European Union. J Nat Conserv 31: 22-28.

Kouba A, Petrusek A, Kozák P. 2014. Continental-wide distribution of crayfish species in Europe: update and maps. Knowl Manag Aquat Ecosyst 413: 5.

Kouba A, Tíkal J, Císař P, et al. 2016. The significance of droughts for hyporheic dwellers: evidence from freshwater crayfish. Sci Rep 6: 26569.

Koutrakis E, Perdikaris C, Machino Y, Savvidis G, Margaris N. 2007. Distribution, recent mortalities and conservation measures of crayfish in Hellenic fresh waters. B Fr Pêche Piscic 385: 25-44.

Kozubíková E, Petrusek A, Duris Z, Martin MP, Dieguez-Uribeondo J, Oidtmann B. 2008. The old menace is back: Recent crayfish plague outbreaks in the Czech Republic. Aquaculture 274: 208-217.

Lipták B, Vitázková B. 2015. Beautiful, but also potentially invasive. Ekol (Bratislava) 34: 155-162.

Lipták B, Mrugała A, Pekárik L, et al. 2016. Expansion of the marbled crayfish in Slovakia: beginning of an invasion in the Danube catchment? J Limnol 75: 305-312.

Lodge DM, Taylor CA, Holdich DM, Skurdal J. 2000. Nonindigenous crayfishes threaten North American freshwater biodiversity: Lessons from Europe. Fisher 25: 7-20.

Lőkkös A, Müller T, Kovács K, Várkonyi L, Specziár A, Martin P. 2016. The alien, parthenogenetic marbled crayfish (Decapoda: Cambaridae) is entering Kis-Balaton (Hungary), one of Europe's most important wetland biotopes. Knowl Manag Aquat Ecosyst 417: 16.

Lowe S, Browne M, Boudjelas S, De Poorter M. 2000. 100 of the world's worst invasive alien species: a selection from the global invasive species database. Invasive Species Specialist Group Auckland, New Zealand.

Lukhaup C, Pekny R. 2006. Cherax (Cherax) holthuisi, a new species of crayfish (Crustacea: Decapoda: Parastacidae) from the centre of the Vogelkop Peninsula in Irian Jaya (West New Guinea), Indonesia. Zool Med Leiden 80: 101-107.

Magalhães ALB, Jacobi CM. 2013. Invasion risks posed by ornamental freshwater fish trade to southeastern Brazilian rivers. Neotrop Ichthyol 11: 433-441.

Martin P, Kohlmann K, Scholtz G. 2007. The parthenogenetic Marmorkrebs (marbled crayfish) produces genetically uniform offspring. Naturwissenschaften 94: 843-846.

Martin P, Dorn NJ, Kawai T, van der Heiden C, Scholtz G. 2010. The enigmatic Marmorkrebs (marbled crayfish) is the parthenogenetic form of Procambarus fallax (Hagen, 1870). Contr Zool 79: 107-118.

Martin P, Thonagel S, Scholtz G. 2016. The parthenogenetic Marmorkrebs (Malacostraca: Decapoda: Cambaridae) is a triploid organism. J Zool Syst Evol Res 54: 13-21.

Moorhouse TP, Macdonald DW. 2015. Are invasives worse in freshwater than terrestrial ecosystems? WIREs Water 2: 1-8.

Mrugała A, Kozubíková-Balcarová E, Chucholl C, et al. 2015. Trade of ornamental crayfish in Europe as a possible introduction pathway for important crustacean diseases: crayfish plague and white spot syndrome. Biol Invas 17: 1313-1326.

Nonnis Marzano F, Scalici M, Chiesa S, Gherardi F, Piccinini A, Gibertini G. 2009. The first record of the marbled crayfish adds further threats to fresh waters in Italy. Aquat Invas 4: 401-404.

Novitsky R, Son M. 2016. The first records of Marmorkrebs [Procambarus fallax (Hagen, 1870) f. virginalis] (Crustacea, Decapoda, Cambaridae) in Ukraine. Ecol Monteneg 5: 44-46.
Padilla DK, Williams SL. 2004. Beyond ballast water: aquarium and ornamental trades as sources of invasive species in aquatic ecosystems. Front Ecol Environ 2: 131-138.

Papavlasopoulou I, Vardakas L, Perdikaris C, Kommatas D, Paschos I. 2013. Ornamental fish in pet stores in Greece: a threat to biodiversity? Mediterr Mar Sci 15: 126-134.

Patoka J, Fisáková MN, Kalous L, Škrdla P, Kuča M. 2014a. Earliest evidence for human consumption of crayfish. Crustaceana 87: $1578-1585$.

Patoka J, Kalous L, Kopecký O. 2014b. Risk assessment of the crayfish pet trade based on data from the Czech Republic. Biol Invas 16: 2489-2494.

Patoka J, Petrtýl M, Kalous L. 2014c. Garden ponds as potential introduction pathway of ornamental crayfish. Knowl Manag Aquat Ecosyst 414: 13.

Patoka J, Kalous L, Kopecký O. 2015. Imports of ornamental crayfish: the first decade from the Czech Republic's perspective. Knowl Manag Aquat Ecosyst 416: 4.

Peay S. 2009. Invasive non-indigenous crayfish species in Europe: recommendations on managing them. Knowl Manag Aquat Ecosyst 394-395: 3.

Perdikaris C, Kozák P, Kouba A, Konstantinidis E, Paschos I. 2012. Socio-economic drivers and non-indigenous freshwater crayfish species in Europe. Knowl Manag Aquat Ecosyst 404: 1.

Ploeg A. 2013. Trade-the status of the ornamental aquatic industry. Ornament Fish Int $J$ 72: 11-13.

Rani P, Immanuel S, Kumar NR. 2014. Ornamental fish exports from India: Performance, competitiveness and determinants. Int J Fish Aquat Stud 1: 85-92.

Reynolds JD. 2011. A review of ecological interactions between crayfish and fish, indigenous and introduced. Knowl Manag Aquat Ecosyst 401: 10.

Rezinciuc S, Sandoval-Sierra J, Oidtmann B, Diéguez-Uribeondo J. 2016. The biology of crayfish plague pathogen Aphanomyces astaci: current answers to most frequent questions. In: Kawai $T$, Faulkes Z, Scholtz G, eds. Freshwater crayfish: a global overview. CRC Press, pp. 182-204.

Rodriguez CF, Becares E, Fernandez-Alaez M, Fernandez-Alaez C. 2005. Loss of diversity and degradation of wetlands as a result of introducing exotic crayfish. Biol Invas 7: 75-85.

Samardžić M, Lucić A, Maguire I, Hudina S. 2014. The first record of the marbled crayfish (Procambarus fallax (Hagen, 1870) $\mathrm{f}$. virginalis) in Croatia. Crayfish News 36: 4.

Seitz R, Vilpoux K, Hopp U, Harzsch S, Maier G. 2005. Ontogeny of the Marmorkrebs (marbled crayfish): a parthenogenetic crayfish with unknown origin and phylogenetic position. J Exp Zool Part A 303: 393-405.

Silas E, Gopalakrishnan A, Ramachandran A, et al. 2011. Guidelines for green certification of freshwater ornamental fish. Kochi, India: Marine Products Export Development Authority.

Souty-Grosset C, Holdich DM, Noël PY, Reynolds J, Haffner P. 2006. Atlas of Crayfish in Europe. Collection Patrimoines Naturels, Muséum National d'Histoire Naturelle, Paris, Vol. 64, $187 \mathrm{p}$.

Souty-Grosset C, Anastácio PM, Aquiloni L, et al. 2016. The red swamp crayfish Procambarus clarkii in Europe: impacts on aquatic ecosystems and human well-being. Limnologica 58: 78-93.

Strayer DL. 2010. Alien species in fresh waters: ecological effects, interactions with other stressors, and prospects for the future. Freshwat Biol 55: 152-174.

Svärdson G. 1995. The early history of signal crayfish introduction into Europe. Freshwat Crayfish 8: 68-77. 
Svoboda J, Mrugała A, Kozubíková-Balcarová E, Petrusek A. 2016. Hosts and transmission of the crayfish plague pathogen Aphanomyces astaci: a review. J Fish Dis: 1-14.

Swahn JÖ. 2004. The cultural history of crayfish. B Fr Pêche Piscic 372-373: 243-251.

Tricarico E, Vilizzi L, Gherardi F, Copp GH. 2010. Calibration of FI-ISK, an invasiveness screening tool for nonnative freshwater invertebrates. Risk Anal 30: 285-292.

Turkmen G, Karadal O. 2012. The survey of the imported freshwater Decapod species via the ornamental aquarium trade in Turkey. J Anim Vet Adv 11: 2824-2827.

Twardochleb LA, Olden JD, Larson ER. 2013. A global meta-analysis of the ecological impacts of nonnative crayfish. Freshw Sci 32: $1367-1382$.

Unestam T. 1972. On the host range and origin of the crayfish plague fungus. Reports from the Inst of Freshw Res 52: 192-198.

Van Wilgen NJ, Wilson JRU, Elith J, Wintle BA, Richardson DM. 2010. Alien invaders and reptile traders: what drives the live animal trade in South Africa? Anim Conserv 13: 24-32.

Veselý L, Buřič M, Kouba A. 2015. Hardy exotics species in temperate zone: can "warm water" crayfish invaders establish regardless of low temperatures? Sci Rep 5: 16340.
Vilà M, Basnou C, Pysek P, et al. 2010. How well do we understand the impacts of alien species on ecosystem services? A panEuropean, cross-taxa assessment. Front Ecol Environ 8: 135-144 .

Vogt G. 2008. The marbled crayfish: a new model organism for research on development, epigenetics and evolutionary biology. J Zool 276: 1-13.

Vogt G. 2015. Bimodal annual reproductive pattern in laboratoryreared marbled crayfish. Invertebr Repr Dev 59: 218-223.

Vogt G, Tolley L. 2004. Brood care in freshwater crayfish and relationship with the offspring's sensory deficiencies. $J$ Morphol 262: 566-582.

Vojkovská R, Horká I, Tricarico E, Duris Z. 2014. New record of the parthenogenetic marbled crayfish Procambarus fallax f. virginalis from Italy. Crustaceana 87: 1386-1392.

Wang Q, Cheng L, Liu J, Li Z, Xie S, De Silva SS. 2015. Freshwater aquaculture in PR China: trends and prospects. Rev Aquacult 7: 283-302.

Weiperth A, Csányi B, Gál B, et al. 2015. Egzotikus rák-, hal- és kétéltűfajok a Budapest környéki víztestekben [Exotic crayfish, fish and amphibian species in various water bodies in the region of Budapest]. Pisces Hungar 9: 65-70.

Cite this article as: Kotovska G, Khrystenko D, Patoka J, Kouba A. 2016. East European crayfish stocks at risk: arrival of non-indigenous crayfish species. Knowl. Manag. Aquat. Ecosyst., 417, 37. 